\title{
Wound Healing Activities of Hydrolyzed Virgin Coconut Oil (HVCO) and Fucoidan Combination: An In Vitro Assay
}

\author{
Sagala Evayanti Meiliana ${ }^{*}$, Silalahi Jansen², Yuandani1 \\ ${ }^{1}$ Department of Pharmacology, Faculty of Pharmacy, University of Sumatera Utara, Medan, \\ Indonesia. \\ ${ }^{2}$ Department of Pharmaceutical Chemistry, Faculty of Pharmacy, University of Sumatera Utara, \\ Medan, Indonesia.
}

\section{A B S T R A C T}

Objective: The aim of this study was to investigate the wound healing activity of hydrolyzed virgin coconut oil (HVCO) and fucoidan combination, in the NIH 3T3 cell line using in vitro assay, and compared with HVCO and fucoidan alone.

Methods: NIH 3T3 Cell proliferation was assessed using the MTT method, migration activity was assessed using sctrach wound healing assays and expression of COX-2 and VEGF protein were determined using immunocytochemistry (ICC).

Results: The results from the proliferative activity assay showed that the best concentrations for all samples were $31.25 \mu \mathrm{g}$ $/ \mathrm{ml}$. NIH 3T3 cells migration activity assay showed that the best combination of the HVCO and fucoidan was 50:50.From COX 2 and VEGF protein expression test results, the combination of HVCO and fucoidan has a higher percentage of expression than $\mathrm{HVCO}$ or fucoidan alone.

Conclusion: The results reveal that the combination of HVCO and fucoidan had better wound healing activity than HVCO or fucoidan alone.

Keywords: MTT, Proliferation, Migration, Immunocytochemistry

A R T I C L E I N F O: Received 1May 2019; Review Completed 3June 2019; Accepted 8 June 2019; Available online 15 June 2019
Cite this article as:
Sagala E M, Silalahi J, Yuandani, Wound Healing Activities of Hydrolyzed Virgin Coconut Oil (HVCO) and Fucoidan
Combination: An In Vitro Assay, Asian Journal of Pharmaceutical Research and Development. 2019; 7(3):40-45
DoI: http://dx.doi.org/10.22270/ajprd.v7i3.532
*Address for Correspondence:
Evayanti Meiliana Sagala, Department of Pharmacology, Faculty of Pharmacy, University of Sumatera Utara, Medan,
Indonesia

\section{INTRODUCTION}

$\mathrm{W}$ ounds can be defined as the occurrence of damage to living tissue or the rupture of the integrity of the epithelium of the upper layer of the skin. Human skin is the largest organ in the body that covers the outer layer, and is divided into three main layers namely the epidermis, dermis, and hypodermis (sub cutaneous). The skin acts as a guard for internal organs, providing protection from microbes, regulating body temperature, and as a place for touch, heat and cold receptors ${ }^{1}$. Wound Healing is a natural phenomenon, occurs by replacing devitalized and missing cellular structure and tissue layers of the skin, this process consists of four highly integrated and overlapping phases: hemostasis, inflammation, proliferation, and tissue remodeling orresolution ${ }^{2,3}$.

Virgin coconut oil (VCO) contains mainly medium chain fatty acids especially lauric acid, easily absorbed, has the potential to accelerate cell metabolism and moisten wound. Previous research has shown that Hydrolyzed virgin coconut oil (HVCO) biological activity is better than virgin coconut oil (VCO) ${ }^{4}$. Previous research also has proven the potential of angiogenesis and wound healing from fermented virgin coconut oil, both in vivo and in vitro ${ }^{5}$.Fucoidans are a family of sulphated polyfucose polysaccharides, have attracted considerable biotechnological research interest since the discovery that they possessed anti-coagulant activities similar to those of heparin. Fucoidan are also reported to possess other properties including antithrombotic, anti- adhesive and anti-viral effects. Many of these effects are thought to be due to their interactions with growth factors such as basic fibroblast growth factor (bFGF) and transforming growth factor-b (TGF-b). Fucoidans may, there fore, be able to modulate growth factor-dependent pathways in the cell biology of tissue repair ${ }^{6}$.

The purpose of this study was to determine wound healing activities from HVCO in combination with fucoidan in NIH 3T3 cell culture with in vitro assay, and compared with $\mathrm{HVCO}$ and fucoidan alone. Cell proliferation activity 
were carried out by the MTT method, while the cell migration activity was carried out using the scratch migration assay method. Protein expression activity that regulates the process of angiogenesis (COX-2 and VEGF) using the immunocytochemistry method.

\section{MATERIALS AND METHODS}

\section{MATERIALS}

Hydrolyzed Virgin Coconut Oil (HVCO), Fucoidan (PT. Kalbe Farma Tbk., Indonesia), Aloclair ${ }^{\circledR}$ Plus Gel (PT. Kalbe Farma Tbk, Indonesia) as a positive control, Dulbecco's Modified Eagle medium (DMEM) complete medium, Fetal Bovine Serum (FBS) 10\% (v/v) (Gibco), penicillin-streptomisin $2 \%(\mathrm{v} / \mathrm{v})$ (Gibco), dan Fungizon (amfoterisin B) 0,5\%. 0,25\% tripsin-EDTA (Gibco), Phospate Buffer Saline (PBS), MTT (3-(4,5dimetiltiazol-2-il)-2,5 difeniltetrazolium bromide) (Sigma),Sodium Dodesil Sulphatet (SDS), beta mercapthoethanol, ethanol 70\%, $\mathrm{HCl}$ 0,1 N (Merck)

\section{METHODS}

\section{NIH 3T3 Cell proliferation activity assay}

This procedure was purpose to determine the best concentration of sampels. 10,000 cells/well in DMEM complete medium were seeded into 96-well plates, incubate in a humidified atmosphere $\left(5 \% \mathrm{CO}_{2}\right)$ at $37 . \mathrm{C}$. After $24 \mathrm{hrs}$, growth medium DMEM complete medium was replaced with medium containing different concentrations of HVCO, fucoidan and positive control. Subsequent to incubation for $24 \mathrm{hrs}$, cells proliferation activitywas determined by MTT assay. Briefly, $100 \mathrm{ml}$ of medium containing $10 \mathrm{ml}$ MTT $(5 \mathrm{mg} / \mathrm{ml})$ was added into each well and incubated for $4 \mathrm{~h}$. The MTT reaction was stopped with a reagent stopper $(10 \%$ SDS in $0.01 \mathrm{~N} \mathrm{HCl})$, the wrapped plate was left for one night in room temperature. Uptake is read by a Microplate Reader (Biorad) at a wavelength of $595 \mathrm{~nm}$. Tests are carried out with three repetitions for each sample. The data which were absorbed from each well were converted to percentage of viable cells ${ }^{7}$. The concentration of the sampels with the highest percentage of cells proliferation activitywere the best concentration for the samples.

\section{Cell Migration activity Assay}

The migration activity was aim to determine the combination with the best activity, a series of HVCO and fucoidan concentrations were made in 3 series with a comparison between HVCO and Fucoidan with a ratio of $50: 50 ; \quad 75: 25 ; \quad 25: 75$ percent of each effective concentration value. The method used is the scratch wound assay. NIH 3T3 cells were seeded in complete medium DMEM at $5 \times 10^{4}$ cells/well in 24-well plates and incubated for $24 \mathrm{~h}$ at $37^{\circ} \mathrm{C}$. Cultured cells were washed with PBS and added culture media which containing $0.5 \%$ FBS and incubated for $24 \mathrm{~h}$. Scratch was done in the bottom center of the well within cell layer using yellow tip. Residues cell in the plate were washed with PBS and treated with EAF and incubated for $72 \mathrm{~h}$ at $37^{\circ} \mathrm{C}$ and documented under inverted microscope against cell migration rapidity after $0,24,48$ and $72 \mathrm{hrs}$. The space from scratch treatment between control and treatment cultur cell was quantified using Image $J$ software and defined as cell migration area. The combination with the best activity was used in protein expression of COX-2 and VEGF assay.

\section{Expression of COX-2 and VEGF proteins activity assay}

Examination of COX-2 and VEGF proteins was carried out at the best combination concentration carried out using the immunocytochemistry (ICC) method. 5x10 cells /wells of NIH 3 T3 cell cultures were transferred into a 24-well plate filled with a cover slip, then the cells were incubated overnight at $37^{\circ} \mathrm{C}$ in a $5 \% \mathrm{CO}_{2}$ incubator. After the cells recover, they are treated by giving the test material and re-incubating for one night. At the end of the incubation time, PBS cells were washed and then cold methanol was added and incubated at room temperature for 10 minutes. The fixed cells were then washed with distilled water 2 times and then incubated in a hydrogen peroxidase solution for 10 minutes. Furthermore, cells were dripped with prediluted serum blocking and incubated 10 minutes. Then it was dropped with primary Monoclonal antibodies for COX-2 and VEGF (1:50 dilution), incubated for 10 minutes, and washed in PBS 3 times. The preparations were incubated in biotin for 10 minutes and washed with PBS 2 times for 5 minutes. After washing with PBS, the cell is dripped with secondary antibodies (biotinylated universal secondary antibody) and injected back for 10 minutes. Then the preparations were incubated in streptavidin-peroxidase for 10 minutes and washed with PBS twice for 5 minutes. Next, the preparations were washed again with PBS and then incubated in $\mathrm{DAB}$ for 10 minutes and washed with distilled water. The preparation was then immersed in Mayer-Haematoxylin solution for 3-4 minutes for counterstain and washed with distilled water. The slip cover is then lifted and dipped in xylol, then dipped in alcohol. After drying, the slip cover is placed on the glass object and pressed with glue (mounting media). Cover slip is covered with a slide then an observation with a microscope. Observations were carried out by microscopes equipped with optical fiber, each dosage was observed in five fields of view with even distribution. The documentation results were then analyzed by using Software Optilab Viewer Image Raster to saw the number of cells expressing the protein.

\section{Statistical analysis}

Normality of the data was performed with the ShapiroWilktest. Statistical analysis was performed by the oneway ANOVA with tukey test for homogenous subsets ( $\alpha$ $<0,05)$.

\section{RESULT \& DISCUSSION}

\section{NIH 3T3 Cells proliferative activity}

MTT method was used to determine cell proliferation activity after incubation for 24 hours. The result of percentage of cell Proliferation at various concentrations can be seen in Table 1. Cell control was assumed to have a percentage of live cell counts of $100 \%$. The highest percentage of living cells for the results of $\mathrm{HVCO}$ was at a concentration of $31.25 \mu \mathrm{g} / \mathrm{ml}$, this concentration was considered as the best concentration for the HVCO. For the fucoidan, the highest percentage of living cells was found at a concentration of $31.25 \mu \mathrm{g} / \mathrm{ml}$, this concentration was also considered the best concentration for the fucoidan. As for positive control (Aloclair ${ }^{\circledR}$ ), the highest 
percentage of living cells at concentration of $125 \mu \mathrm{g} / \mathrm{ml}$, but this result was not much different from the sample concentration of $31.25 \mu \mathrm{g} / \mathrm{ml}$. Therefore the concentration of $31.25 \mu \mathrm{g} / \mathrm{ml}$ was considered to be the best concentration, because with smaller doses or concentrations it can produce almost the same effect with larger doses. From the data above, the results of best concentrations for all samples were $31.25 \mu \mathrm{g} / \mathrm{ml}$.

Table 1: NIH 3T3 cells proliferation activity at various concentrations

\begin{tabular}{|c|c|c|}
\hline Sampels & Concentration & Cells proliferation percentage $(\%)$ \\
\hline \multirow{6}{*}{ HVCO } & $500 \mu \mathrm{g} / \mathrm{ml}$ & $10,8333 \pm 0,55120^{*}$ \\
\hline & $250 \mu \mathrm{g} / \mathrm{ml}$ & $26,7363 \pm 3,75075^{*}$ \\
\hline & $125 \mu \mathrm{g} / \mathrm{ml}$ & $129,5833 \pm 5,63027^{*}$ \\
\hline & $62,5 \mu \mathrm{g} / \mathrm{ml}$ & $133,7500 \pm 0,24076^{*}$ \\
\hline & $31,25 \mu \mathrm{g} / \mathrm{ml}$ & $139,4443 \pm 1,52311^{*}$ \\
\hline & $15,625 \mu \mathrm{g} / \mathrm{ml}$ & $89,0377 \pm 0,57783$ \\
\hline \multirow{6}{*}{ Fucoidan } & $500 \mu \mathrm{g} / \mathrm{ml}$ & $106,5280 \pm 4,98008$ \\
\hline & $250 \mu \mathrm{g} / \mathrm{ml}$ & $109,8610 \pm 1,99221$ \\
\hline & $125 \mu \mathrm{g} / \mathrm{ml}$ & $113,1943 \pm 8,57484$ \\
\hline & $62,5 \mu \mathrm{g} / \mathrm{ml}$ & $121,2503 \pm 4,92566$ \\
\hline & $31,25 \mu \mathrm{g} / \mathrm{ml}$ & $121,1807 \pm 8,94639$ \\
\hline & $15,625 \mu \mathrm{g} / \mathrm{ml}$ & $89,0377 \pm 0,49661$ \\
\hline \multirow{6}{*}{ Aloclair $^{\circledR}$} & $500 \mu \mathrm{g} / \mathrm{ml}$ & $127,2917 \pm 1,57728^{*}$ \\
\hline & $250 \mu \mathrm{g} / \mathrm{ml}$ & $156,2503 \pm 4,63980^{*}$ \\
\hline & $125 \mu \mathrm{g} / \mathrm{ml}$ & $156,7360 \pm 5,30664 *$ \\
\hline & $62,5 \mu \mathrm{g} / \mathrm{ml} / \mathrm{ghol}$ & $152,1527 \pm 3,95362 *$ \\
\hline & $31,25 \mu \mathrm{g} / \mathrm{ml}$ & $145,6250 \pm 7,55294 *$ \\
\hline & $15,625 \mu \mathrm{g} / \mathrm{ml}$ & $88,3540 \pm 0,54317 *$ \\
\hline Cells control & & $100,0000 \pm 5,92664$ \\
\hline Medium control & & $0,0000 \pm 4,82857 *$ \\
\hline
\end{tabular}

\section{NIH 3 T3 cells migration activity}

The migration method is used to measure the percentage of wound closure by the test material. Migration is a key property of live cells and critical for normal development, immune response ${ }^{8}$. Cell migration is a complex phenomenon related to many cellular processes. Migration testing was done by scraping monolayer cells using sterile yellow tips until a certain size of stroke was formed. Determination of cell migration ability was done by quantifying the width of the stroke at 0 hour and at certain time intervals until the cells migrate to cover the scratches. This measurement directly allows to know the effect of a compound with different concentrations on the ability of cell interactions during cell migration. From the results of calculating the percentage of wound closure, which was calculated based on the initial empty area compared to the area after incubation in Image $\mathbf{J}$ software, the data in Table 2 is obtained. Wound healing activities from the sampels based on NIH $3 \mathrm{~T} 3$ cells migration assay can be seen in Figure 1. 
Table 2: Percentage of wound closure from the test material by NIH 3 T3 cell migration testing with the incubation period of 24 hours, 48 hours and 72 hours.

\begin{tabular}{|c|c|c|c|c|}
\hline \multirow{2}{*}{ S. No } & \multirow{2}{*}{ Sampels } & \multicolumn{3}{|c|}{ Percentage of wound closure (\%) } \\
\hline & & 24 hours & 48 hours & 72 hours \\
\hline 1 & Cells control & $15,2433 \pm 0,41478$ & $74,3600 \pm 0,45574$ & $100,0000 \pm 0,0000$ \\
\hline 2 & Aloclair $^{\circledR}$ & $28,5767 \pm 0,45157^{*}$ & $82,5467 \pm 0,91732^{*}$ & $92,7167 \pm 0,54272^{*}$ \\
\hline 3 & Fucoidan & $29,7100 \pm 0,58158^{*}$ & $85,6167 \pm 0,30322 *$ & $100,0000 \pm 0,0000^{*}$ \\
\hline 4 & HVCO & $62,3700 \pm 0,44736^{*}$ & $100,0000 \pm 0,0000^{*}$ & $100,0000 \pm 0,0000^{*}$ \\
\hline 5 & 50:50HVCO Fucoidan combination & $77,5067 \pm 0,28620^{*}$ & $100,0000 \pm 0,0000^{*}$ & $100,0000 \pm 0,0000^{*}$ \\
\hline 6 & 25:75 HVCO Fucoidan combination & $2,5433 \pm 0,16496^{*}$ & $-3,3267 \pm 0,20755^{*}$ & $-18,2367 \pm 0,02404^{*}$ \\
\hline 7 & 75:25 HVCO Fucoidan combination & $-9,0700 \pm 0,35346^{*}$ & $-18,4765 \pm 0,02404 *$ & $-29,2733 \pm 0,29157^{*}$ \\
\hline
\end{tabular}

Values are expressed as mean \pm SEM using one way ANOVA; $n=3$ in each group *p<0, 05: significantly different with cell control

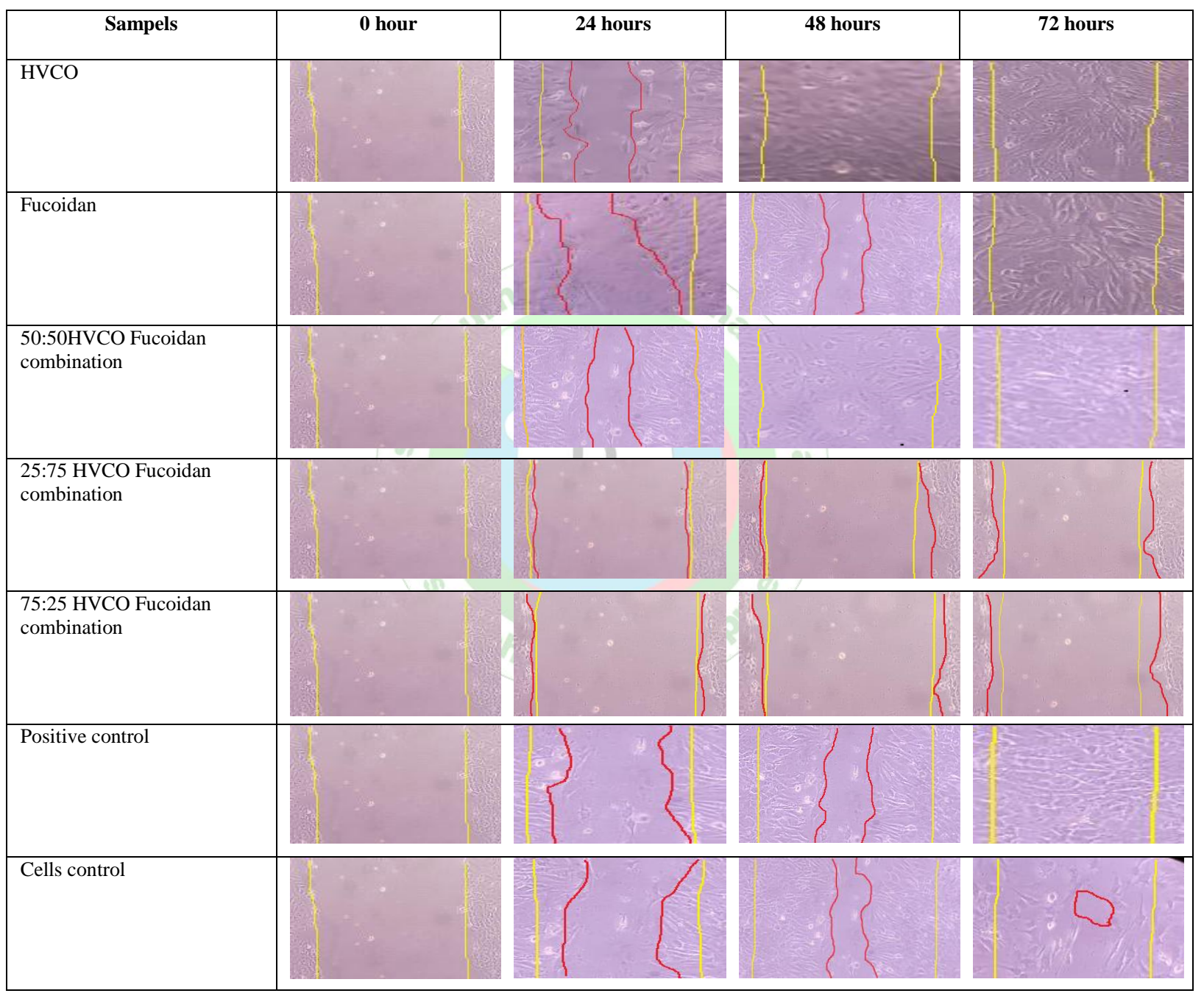

Figure 1: Documentation of the wound closure process of the samples at 0 hours, 24 hours, 48 hours and 72 hours.

The results of NIH $3 \mathrm{~T} 3$ cells migration activity assay showed that the best combination of the HVCO and fucoidan was 50:50, so that the best combination would be used for further eksperiment of protein COX-2 and VEGF expression activity by immunocytochemistry (ICC) method.

\section{Expression of COX-2 and VEGF protein activity assay}

Immunocytochemistry (ICC) is a method that used to detect the expression of a specific protein or antigen in cells using specific antibodies that will bind to proteins or antigens. Data obtained in this test in the form of a percentage was the percentage comparison of cells expressing proteins from the total number of cells. Data analysis was performed to calculate the number of cells expressing COX-2 and VEGF proteins using Optilab Viewer 2.2 Image Raster software. The results of the analysis are through image quantification from an average of 5 (five) fields of view. Cells that are brown/ dark cell cytoplasm mean expressing the protein, while blue cells mean not expressing protein. 


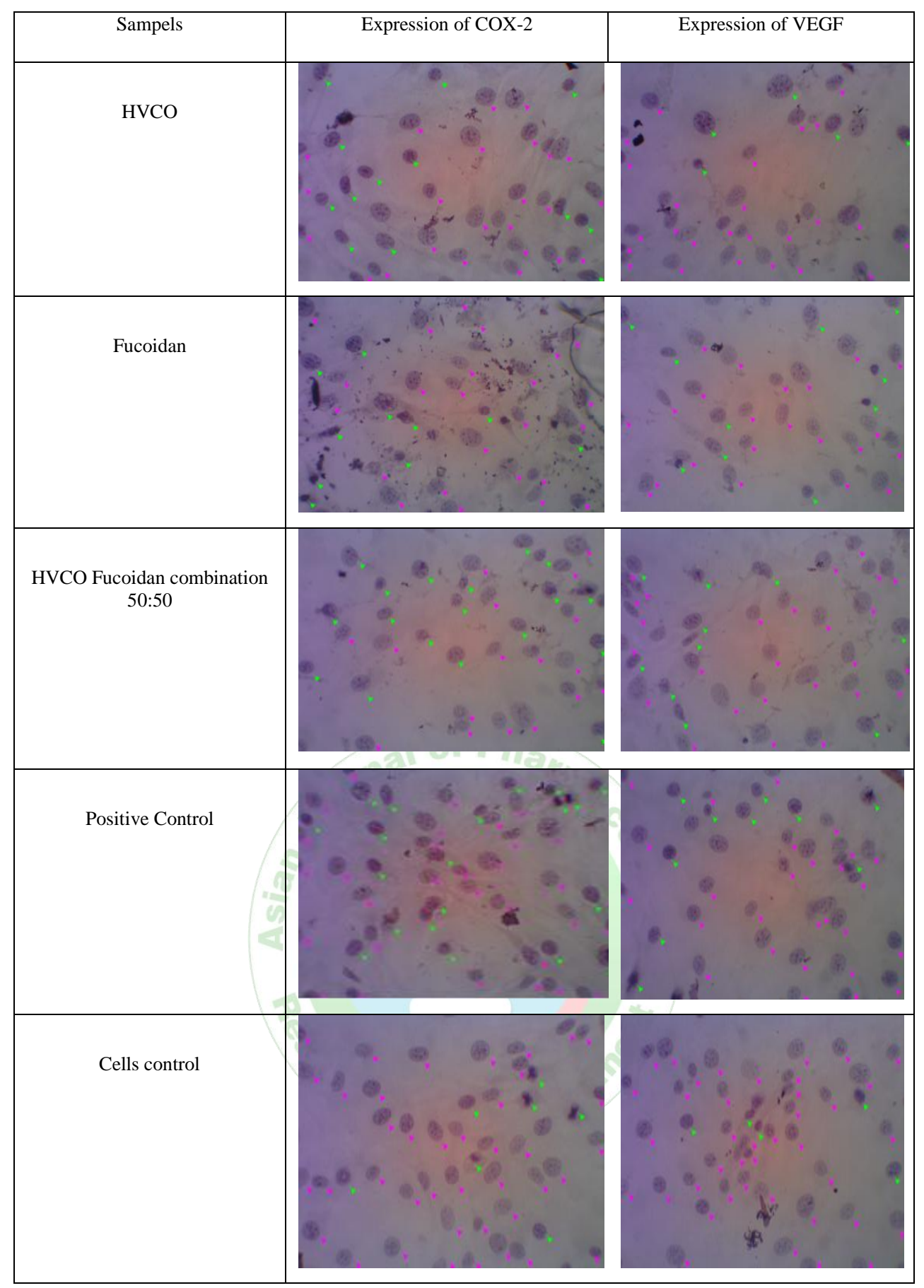

Figure 2: Observation of cells using a microscope equipped with an optilab camera (40x magnification).

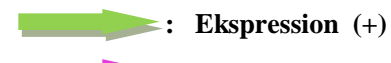

: Ekspression (+)
Ekspression (-)

Data on the percentage of COX-2 and VEGF protein expression can be seen in Table 3:

Table 3: Percentage of COX-2 and VEGF protein expression

\begin{tabular}{|l|l|l|l|}
\hline No & Sampels & \% COX-2 protein expression & \% VEGF protein expression \\
\hline 1 & Cells control & $6,4816 \pm 0,29969$ & $7,3599 \pm 0,23778$ \\
\hline 2 & Aloclair $^{\circledR}$ & $27,1261 \pm 0,28401^{*}$ & $33,2574 \pm 0,36119^{*}$ \\
\hline 3 & HVCO & $28,4203 \pm 0,25630^{*}$ & $25,4550 \pm 0,21897^{*}$ \\
\hline 4 & Fucoidan & $26,8923 \pm 0,10610^{*}$ & $27,4068 \pm 0,24609^{*}$ \\
\hline 5 & $50: 50$ HVCO dan Fucoidan combination & $34,7558 \pm 0,09872^{*}$ & $30,0957 \pm 0,29865^{*}$ \\
\hline
\end{tabular}

Values are expressed as mean \pm SEM using one way ANOVA; $n=3$ in each group

${ }^{*} \mathrm{p}<0,05$ : significantly different with cell control 
From the percentage data above, it was found that the highest COX-2 protein expression was found in the combination test results of hydrolysis of virgin coconut oil and fucoidan 50:50, which was $34.7558 \%$. This result was $7.8635 \%$ higher than single fucoidan (26.8923\%), $6.3355 \%$ higher than the yield of single HVCO $(28.4203 \%)$ and $7.6297 \%$ higher than positive control (27, $1261 \%$ ). For own cell control, percent of COX-2 protein expression was $6.4816 \%$.

Whereas the highest VEGF protein expression was found in the positive control of $33.2574 \%$. For the samples, the combination of $\mathrm{HVCO}$ and fucoidan 50:50, percent protein expression amounted to $30.0957 \%$. These results were $2.6889 \%$ higher than fucoidan $(27.4068 \%)$ and $4.6407 \%$ higher than the yield of HVCO $(25.4550 \%)$. For own cell control, percent of VEGF protein expression was $7.3599 \%$.

Previous research has proven the potential of angiogenesis and wound healing from fermented virgin coconut oil,

\section{REFERENCES}

1. Pratsinis H, Mavrogonatou E, and Kletsas D. Scarless Wound Healing: From Development to Senescence. Advanced Drug Delivery Reviews. 2018; 18:1-11.

2. Guo S, and Dipietro L A. Factors Affecting Wound Healing. J Dent Res. 2010; 89(3):219-229.

3. Shrivastav A, Mishra A K, Ali S S, Ahmad A, Abuzinadah M F, and Khan N A. In Vivo Models for Assesment of Wound Healing Potential: A Systematic Review. Wound Medicine. 2018; 20:43-53.

4. Silalahi J, and Surbakti C. Burn Wound Healing Activity of Hydrolyzed Virgin Coconut Oil. International Journal of Pharma Tech Research. 2015; 8(1):67-73.

5. Ibrahim A H, Li H, Al-Rawi S S, Majid A S A, Al-Habib, O A, Xia $\mathrm{X}$, dkk. Angiogenic and Wound Healing Potency of Fermented Virgin Coconut Oil : In Vitro and In Vivo Studies. Am J Transl Res. 2017; 9(11):4936-4944.

6. O'Leary R, Rerek M, and Wood J W. Fucoidan Modulates the Effects of Transforming Growth Factor (TGF)- $\beta 1$ on Fibroblast both in vivo and in vitro ${ }^{5}$. Park, et al. (2017) conducted a study on wound healing activity from fucoidan by in vivo. From the results of the study it can be concluded that fucoidan can accelerate incision wound healing in mice characterized by narrowing of the area of the wound and increased expression of TGF- $\beta 1$, VEGFR and MMP $9^{9,10}$.

\section{CONCLUSIONS}

The results from the proliferative activity assay showed that the best concentrations for all sampels were 31,25 $\mu \mathrm{g} / \mathrm{ml}$. NIH $3 \mathrm{~T} 3$ cells migration activity assay showed that the best combination of the HVCO and fucoidan was 50:50. From COX-2 and VEGF proteins expression test results, the combination of $\mathrm{HVCO}$ and fucoidan had a higher percentage of expression than $\mathrm{HVCO}$ or fucoidan alone. From the results above can reveal that the combination of HVCO and fucoidan had better wound healing activity than HVCO or fucoidan alone with invitro assay.

Proliferation and Wound Repopulation an In Vitro Models of Dermal Wound Healing. Biol. Pharm. Bull. 2004; 27(2):266-270.

7. Harahap U, Hasibuan P A Z, Sitorus P, Arfian N, and Satria D. Antimigration Activity of An Ethylacetate Fraction of Zanthoxylum acanpodium DC. Fruits in 4T1 Breast Cancer Cells. Asian Pacific Journal of Cancer Prevention. 2018; 19:565-569.

8. Justus C R, Leffler N, Ruiz-Echevarria M, and Yang L V. In Vitro Cell Migration and Invasion Assay. Journal of Visualized Experiments. 2014; 88:1-8.

9. Park H Y, Han M H, Park C, Jin C Y, Kim G Y, Choi I W, dkk. Anti-Inflammatory Effect of Fucoidan Through Inhibition of Nf-kB, MAPK And Akt Activation In Lipopolysaccharide-Induced BV2 Microglia Cells. Food and Chemical Toxicology. 2011; 49:17451752.

10. Park J H, Choi S H, Park S J, Jin C Y, Lee Y J, Park J H, dkk. Promoting Wound Healing Using Low Molecular Weight Fucoidan in a Full-Thickness Dermal Excision Rat Model. Marine Drugs. 2017; 15:112-127. 